\title{
Screening and Evaluation of Lectin and Anti-Cancer Activity from the Phloem Exudate/Sap of the Indian Dietary Ethnomedicinal
}

\section{Plants}

\author{
Balaji Kyathegowdanadoddi Srinivas', Madhu Chakkere Shivamadhu',2, Preethi Saligrama Devegowda ${ }^{3}$, \\ Gurukar Mathew ${ }^{4}$, Theethagounder Tamizhmani ${ }^{5}$, Senthilkumar Gnanavadevel Prabhakaran ${ }^{5}$, Shankar \\ Jayarama ${ }^{1, *}$
}

\section{Balaji Kyathegowdanadoddi Srinivas ${ }^{1}$, Madhu Chakkere Shivamadhu ${ }^{1,2}$, Preethi Saligrama Devegowda ${ }^{3}$, Gurukar Mathew ${ }^{4}$, Theethagounder Tamizhmani ${ }^{5}$, Senthilkumar Gnanavadevel Prabhakaran5, Shankar Jayarama ${ }^{1, *}$}

'Post-Graduation Department of Biotechnology, Teresian College, Siddhartha Nagara, Mysore, Karnataka 570011, INDIA.

2Department of Biochemistry, Yuvaraja's College, University of Mysore, Mysuru, Karnataka 570005, INDIA

${ }^{3}$ Department of Studies in Biotechnology, University of Mysore, Mysuru, Karnataka 570006, INDIA

${ }^{4}$ Department of Botany, Bharathi College, Affiliated University of Mysore, Bharathi Nagara, KM Doddi, Mandya, Karnataka 571422, INDIA.

${ }^{5}$ Department of Pharmacy, Bharathi College of Pharmacy, Bharathi Nagara, KM Doddi, Mandya, Karnataka 571422, INDIA.

\section{Correspondence}

\section{Dr. Shankar Jayaramaa}

Assistant Professor, Post-Graduation Department of Biotechnology, Teresian Research Foundation (Affiliated to University of Mysore), Siddhartha Nagar, Mysore-570011, Karnataka, INDIA.

E-mail: shankarbio@gmail.com History

- Submission Date: 29-03-2019;

- Review completed: 11-04-2019;

- Accepted Date: 18-04-2019.

DOI : 10.5530/pj.2019.11.91

Article Available online http://www.phcogj.com/v11/i3

\section{Copyright}

(C) 2019 Phcogi.Com. This is an openaccess article distributed under the terms of the Creative Commons Attribution 4.0 International license.

\begin{abstract}
Objective: Lectins are extremely significant biomolecules to study several biological progressions. In this present investigation, we are screening the crude phloem exudate/ sap sample from different ethnomedicinal plants were evaluated for lectin and anticancer activity. Methods: The lectin activity of crude phloem exudate/sap samples were confirmed by haemgglutination assay and anticancer activity by using trypan blue, MTT and in-ovo CAM angiogenic assay. The tumor cell nuclei resulting in Giemsa stain, $\mathrm{AO} / \mathrm{EtBr}$ stain, DNA Fragmentation and Caspase- 3 inhibitor assay. Results: Our experimental data show that the phloem exudate/sap sample S2 (Musa acuminata), sample S4 (Euphorbia geniculate) exerting the potent lectin activity, sample S5 exerting very low lectin activity against the trypsinized rabbit erythrocytes and decreases the cell viability in EAC cells in-vitro. Sample S2, S4 and S5 exerts significant cytotoxic effect against the various human cancer cell lines and regressed the neovasculature (development of new blood vessels) in the developing CAM embryos when compared to the other crude samples. The apoptotic inducing activity of crude phloem exudate/sap samples was revealed by DNA fragmentation assay, caspase-3 inhibitor assay and cellular morphology were studied by fluorescence staining methods. Conclusion: This study reports that some of the isolated crude phloem exudate/sap samples show potent lectin activity and anti-cancer activity in different human cancer cell lines. The further additional experiment needs to purify and characterize the bioactive lectin components from the potent sample which is responsible for pro-apoptotic, anti-angiogenic activity and mechanism involved.
\end{abstract}

Key words: lectin, haemagglutination, EAC, apoptosis, angiogenesis, VEGF.

\section{INTRODUCTION}

Lectins are carbohydrate-binding proteins or glycoproteins, which are found ubiquitously in nature. 'Lectin' originates from the Latin word Legere, which means to select or to choose. ${ }^{1}$ By binding to carbohydrates, lectins serve diverse biological functions. Lectins are present plants, animals, fungi, bacteria with the ability to interact with carbohydrates and agglutinate cells or precipitate glycoconjugates. They play important roles in defence against invasion of bacteria, virus or fungi. ${ }^{2}$ They used in the field of blood lymphocyte stimulation, acumen between normal and malignant cells. Lectins are classified based on their characteristics, binding domains and glycan structures. Interestingly, the majority of cancer biomarkers that are currently being used in the clinical settings are glycoproteins, which are structurally altered in their glycan moieties and aberrantly expressed. ${ }^{3}$ Indeed, changes in glycosylation are believed to be the main feature in oncogenic transformation as glycans are known to be continuously involved in cancer evolving typing diagnosing of microorganisms, mitogenic processes, such as cell signalling, angiogenesis, cellmatrix interactions, immune modulation, tumour cell dissociation and metastasis. ${ }^{4}$

Cancer is one of the most dreaded diseases of the 20th century and spreading further with a continuance and increasing incidence in the 21 st century. Over 9 million new cancer cases are diagnosed and $>4.5$ million people die of cancer P.A in the world. Due to adverse effects and complications, currently available chemotherapeutic agents have limitations in treatment. To overcome this problem, phytoconstituents from the plants exhibiting anti-cancer property is emerging as a tool in the prevention of tumour development. ${ }^{5}$ Over more than $30 \%$ of cancer death was directly associated with dietary food habits. This is due to the changes in dietary and adaptation of a sedentary lifestyle and the burden of this disease are gradually increasing every day. ${ }^{6}$ In the modem era, several researchers involved in order to develop therapeutics against cancer by using the medicinal plants. Lectins from plants are considered to be one of the major sources lectins which localized in various parts of plants. ${ }^{7}$ However, numerous plant-based lectins have been well studied,
Cite this article: Srinivas BK, Shivamadhu MC, Devegowda PS, Mathew G, Tamizhmani T, Gnanavadevel Prabhakaran S, et al. Screening and Evaluation of Lectin and Anti-Cancer Activity from the Phloem Exudate/Sap of the Indian Dietary Ethnomedicinal Plants. Pharmacog J. 2019;11(3):570-8 
but their physiological role of these lectins is poorly understood and it is argued that lectins which exhibit biological role need careful study in order to execute its molecular mechanism in the physiological conditions. Edible/Dietary lectins which are plant protein components with the ability to bind, selectively, free or conjugated saccharide in a reversible way by two or more binding sites, have been shown to induce lymphocyte proliferation or modulate several immune functions including agglutination, immunomodulation, anti-inflammatory, anticancer properties.

The current work exploits the use of edible/dietary medicinal plants available in the local region of Karnataka, India. Five plants, namely Citrullus lanatus, Musa acuminata, Manilkara zapota, Euphorbia geniculate and Abelmoschus esculentus were selected to screen for the presence of lectin and anticancer activity.

All the five plants were previously reported for their medicinal values against various pathological disorders, including, inflammation, diabetes, antibacterial etc. ${ }^{8-15}$ but none of the above plants were screened for lectin and its anti-cancerous activity. The study aimed to exhibit the effectiveness of these plants against apoptosis and angiogenesis.

\section{MATERIAL AND METHODS}

\section{Cells and reagents}

K562 human leukaemia cells, MCF-7 human breast cancer cells, HeLa human cervical cancer cells, HT-29 human colon cancer cells and Ehrlich Ascites Carcinoma (EAC) cells were purchased from National Centre for Cell Sciences (NCCS) Pune, India. MEM, DMEM, Mecoys'5A, RPMI media, PBS, Supplements Fetal Bovine Serum (FBS), Trypsin and Antibiotics were purchased from Gibco, Invitrogen life technologies (Paisley UK). MTT, Caspase-3-Inhibitor, rVEGF $_{165}$ were obtained from Sigma-Aldrich, Inc. (St. Louis, MO, USA). Acridine orange, Ethidium Bromide, Agarose, Trypan blue dye was purchased from SRL, India.

\section{Exudate extraction}

The fresh sap/phloem exudate from the different plants is collected by using a sterile needle as described for the other sap processing with some modifications. ${ }^{16}$ The oozed out sap was mixed with ice-cold $10 \mathrm{mM}$ PBS (pH - 7.4) in the proportion of $1: 10(10 \%, \mathrm{v} / \mathrm{v})$ and immediately kept in the magnetic stirrer at $4{ }^{\circ} \mathrm{C}$ to avoid sap coagulation. After homogenizing for $2-3 \mathrm{hr}$, the suspension was centrifuged at 12,000 $\mathrm{rpm}, 4^{\circ} \mathrm{C}$ for $10 \mathrm{~min}$ to remove coagulated debris. The supernatant with the transparent golden brown extract of plant sap was subjected lyophilisation (Thermo Scientific PowerDry LL1500), used for the further assay. The samples were named as follows, Citrullus lanatus (S1), Musa acuminata (S2), Manilkara zapota (S3) Euphorbia geniculate (S4) and Abelmoschus esculentus (S5) and stored at $-20^{\circ} \mathrm{C}$ and used for the experiments.

\section{Protein analysis}

Protein concentration was determined by Lowry's method, using bovine serum albumin (BSA) as a reference standard with minor modification. ${ }^{17}$ Briefly, $0.5 \mathrm{ml}$ of crude latex samples were incubated with the Lowry reagent for $10 \mathrm{~min}$ at $37^{\circ} \mathrm{C} .0 .5 \mathrm{ml}$ of FC (Folin-Ciocalteu) reagent (1:1) was added to the reaction mixture and incubates the samples for $30 \mathrm{~min}$ at room temperature and absorbance was read spectrophotometrically.

\section{Erythrocytes (RBCs) preparation}

Fresh rabbit blood is collected in a sterile tube, containing an equal volume of the anticoagulant solution (Alsever's Solution) and centrifuged at $2500 \mathrm{rpm}$ for $5 \mathrm{~min}$. Collect the packed cells and repeat the above step until the supernatant becomes colourless and prepare the $2 \%$ of RBC suspensions by using the Alsever's solution. ${ }^{18}$

\section{Haemagglutination assay}

Haemagglutination (HA) tests were done as per the methods, as described earlier. ${ }^{19}$ Briefly, $50 \mu \mathrm{l} 2 \%$ trypsinized rabbit erythrocytes were incubated with crude samples $(1 \mathrm{mg} / \mathrm{ml})$ solution in a U-bottomed 96 well Microtiter plate, gently mixed and incubated at $37^{\circ} \mathrm{C}$ for $1 \mathrm{~h}$ to visualize the agglutination and photograph. Agglutination titter is defined as the minimum amount of lectin required to form a positive agglutination referred to as 1titer value.

\section{Effect of thermal and pH stability of crude phloem exudate/ sap samples}

To determine the thermal stability, crude Phloem exudate/sap samples $(50 \mu \mathrm{g})$ was incubated at various temperatures of $\left(0{ }^{\circ} \mathrm{C}\right.$ to $\left.100{ }^{\circ} \mathrm{C}\right)$ for a period of $30 \mathrm{~min}$ and agglutination activity was carried as described above. For $\mathrm{pH}$ stability, crude Phloem exudate/sap samples were examined using the buffer, ranging from $\mathrm{pH} 2$ to 12 . The buffers used were: $50 \mathrm{mM}$ glycine- $\mathrm{HCl}$ (pH 2 and 3), $50 \mathrm{mM} \mathrm{Na}$-acetate- acetic acid (pH 4 and 5), $10 \mathrm{mM}$ PBS (pH 6 and 7) and $50 \mathrm{mM}$ Tris- $\mathrm{HCl}(\mathrm{pH}$ 8 -12). Crude Phloem exudate/sap samples $(50 \mu \mathrm{g})$ was incubated with the equal volume of buffer for $60 \mathrm{~min}$ and the agglutination assay was performed as described earlier. ${ }^{19}$

\section{Anticancer study}

\section{Animal and ethical statement}

Swiss albino BALB/c female mice, aged 6-8 weeks, weighing $26 \pm 1.5 \mathrm{~g}$ and New Zealand Swiss albino white Rabbit, weighing $1.5 \pm 2 \mathrm{~kg}$ were housed under standard laboratory conditions and fed a diet of animal chow and water ad libitum throughout the experiment. The mice were maintained at the room temperature $\left(22 \pm 2^{\circ} \mathrm{C}\right)$ with a good ventilation for a $12 \mathrm{~h}$ day/night cycle. All the animal experimentations were approved by the Institutional Animal Ethics Committee (IAEC), (Approval No: BCP/IAEC/EXTP/06/2018) Bharathi College of Pharmacy, Bharathi Nagara, Mandya District, India. In accordance with the Committee for the purpose of control and supervision of experiments on animals (CPCSEA) guidelines for laboratory animal facility.

\section{In-vivo ehrlich ascites carcinoma (EAC) cell culture}

The Ehrlich Ascites Carcinoma (EAC) cells were maintained by in-vivo passage in Swiss albino mice. EAC bearing mice were sacrificed and the tumour cells were withdrawn under aseptic conditions. A suspension of the withdraw tumour cells was made in $0.9 \%$ sterile saline. Approximately $\left(5 \times 10^{6}\right.$ cells $\left./ \mathrm{ml}\right)$ EAC cells were injected into the mice intraperitoneal region and growth was recorded from 1st day to14th every day. These cells grow in the mice peritoneum, forming an ascites tumour with massive abdominal swelling. The animals show a dramatic increase in body weight over the growth period and animals surrender to the tumour weight 12-14 days after transplantation. ${ }^{20}$

\section{Preparation of EAC cells}

The cells were isolated from the peritoneal cavity of EAC bearing mice after 10 days of transplantation. Two millilitres (ml) of saline was injected into the peritoneal cavity of mice and the peritoneal fluid containing the tumour cell was withdrawn and cells were washed with ammonium chloride to remove the RBCs, after ammonium chloride washing, again cells were washed with Phosphate buffer saline (PBS) and discard supernatant and repeat the above step twice. The obtained cells were dissolved in saline (1:5 ratio).

\section{Trypan blue dye exclusion assay}

Isolated phloem exudate/sap samples induce the cell viability in EAC cells was determined by trypan blue dye exclusion assay, as described previously. ${ }^{21}$ Briefly, $5 \times 10^{4}$ cells were treated with or without crude 
phloem exudate/sap samples $(200 \mu \mathrm{g}, 100 \mu \mathrm{g}, 50 \mu \mathrm{g}, 25 \mu \mathrm{g}, 12.5 \mu \mathrm{g}, 6.25$ $\mu \mathrm{g}, 3.125 \mu \mathrm{g}$ and $1.5625 \mu \mathrm{g}$ ) for $4 \mathrm{~h}$, stained with $0.25 \%$ trypan blue dye and counted under a microscope using a haemocytometer. The result was expressed as the percentage of viable cells in each treatment group were calculated and plot the graph.

\section{Cell culture and maintenance}

The variant human cancer cell lines, such as breast cancer (MCF7), cervical cancer (HeLa) leukaemia (K562), colon cancer (HT-29), Chang liver cell (CCL-13) and Ehrlich Ascites Carcinoma cell (EAC) were procured from the National Centre for Cell Science (NCCS), Pune, India. The cells are maintained aseptically at $37^{\circ} \mathrm{C}$, in a mixture of MEM media for MCF-7, EAC cell lines, DMAEM media for HeLa cells, RPMI media for K562 cells and Mecoy's 5A Media for HT-29 cells with $100 \mathrm{IU} / \mathrm{ml}$ penicillin, $100 \mu \mathrm{g} / \mathrm{ml}$ streptomycin and $10 \%$ fetal bovine serum (FBS) in a humidified atmosphere, containing $5 \% \mathrm{CO}_{2}$.

\section{MTT assay}

The cytotoxic effect of crude phloem exudate/sap samples was evaluated by using 3-(4, 5 dimethyl- 2-yl) -2, 5 diphenyl tetrazolium bromide (MTT) assay as described earlier. ${ }^{22}$ In brief, $1 \times 10^{4}$ cells were seeded to 96 well plate and cells were exposed to crude phloem exudate/sap samples with a different concentration $(200 \mu \mathrm{g}-1.562$ $\mu \mathrm{g})$. The cytotoxic effect of crude phloem exudate/sap samples was measured by adding $20 \mu \mathrm{l}$ of $(5 \mathrm{mg} / \mathrm{ml})$ MTT solution to each well, incubating at the $37{ }^{\circ} \mathrm{C}$ for $4 \mathrm{~h}$ and reading the plate at $570 \mathrm{~nm}$ (Thermo Scientific Varioskan Flash Multimode Reader).

\section{In-Ovo CAM angiogenesis assay}

The recombinant VEGF165 $\left(\mathrm{rVEGF}_{165}\right)$ induced in-ovo CAM angiogenesis model was executed to study the anti-angiogenic effect of the crude Phloem exudate/sap samples. Fertilized eggs were procured from the local market of Malavalli, Karnataka, India. The eggs were grouped and incubated at $37{ }^{\circ} \mathrm{C}$ in a humidified and the sterile atmosphere for 8 days $(n=5)$. The crude Phloem exudate/sap samples $(10 \mu \mathrm{g} / \mathrm{CAM})$ was treated on the growing CAM by making a small window on the eggshell as described earlier. ${ }^{23,24}$ The windows were opened on the 12th day and inspected for changes in the microvessel density and photographed using a Nikon Digital camera.

\section{Giemsa staining}

Giemsa stain was performed to assess the apoptotic morphology as reported earlier. Briefly, Control and crude phloem exudate/sap samples treated EAC cells were collected and washed with phosphate buffered saline $(20 \mathrm{mM}$, PBS) twice and smeared on a glass slide. Methanol and acetic acid (3:1) were used to fix the cells and stained by Giemsa solution $(0.1 \%)$. The cells were observed under a light microscope and photographed using the CatCam 130 microscopic camera. ${ }^{25,26}$

\section{Fluorescent analysis}

\section{AO/Et Br staining}

Nuclear staining was performed according to the method as described previously. ${ }^{27}$ Both control and crude phloem exudate/sap samples treated EAC cells were collected and washed with phosphate buffered saline (20 mM, PBS) twice and smeared on a glass slide. Methanol and acetic acid (3:1) were used to fix the cells and air dried. The cells were hydrated with PBS and stained with a mixture $(1: 1)$ of acridine orange/ethidium bromide (AO/EtBr) $(4 \mu \mathrm{g} / \mathrm{mL})$ solution in $\mathrm{PBS}$ for 5 to $10 \mathrm{~min}$ in the dark at the room temperature. The cells were immediately washed with PBS and viewed under a fluorescent microscope with the wavelength of $400 \mathrm{~nm}-500 \mathrm{~nm}$ and the cell morphological changes were observed under the fluorescent microscope (Carl Zeiss Axio Imager A2) and photographed.

\section{DNA fragmentation assay}

In-vitro genomic DNA from the EAC cells of control and treated with crude phloem exudate/sap samples were isolated using the phenolchloroform-isoamyl alcohol method as described earlier with minor modifications.$^{28}$ And electrophoresed on $1.5 \%$ agarose gel. The DNA fragmentation was visualized under the Gel Doc system (Bio-Rad Universal Hood II) and documented.

\section{Caspase - 3 inhibitor assay}

Caspase-3 inhibitor assay was performed for evaluating the EAC induced caspase-3 dependent activity. EAC cells were neither or either pre-incubated with caspase-3 inhibitor Ac-DEVD-CHO (100 mM) for $1 \mathrm{hr}$ and treated with or without crude Sample treated for $4 \mathrm{hrs}$. Cells were centrifuged and isolate the DNA and the fragmentation was visualised by $1.5 \%$ agarose gel and Documented. ${ }^{29}$

\section{Statistical analysis}

Values were expressed as a mean \pm standard error (SEM). Statistical significance was evaluated by the one-way analysis of variance (ANOVA), followed by the use of Student's t-test by using the Graph Pad Prism 5.1.

\section{RESULTS}

\section{Crude phloem exudate/sap samples show potent haemagglutinating activity in RBCs}

Crude phloem exudate/sap samples were used to examine for the presence of lectin activity through the haemagglutination assay. The agglutination activity of crude phloem exudate/sap samples confirmations potent lectin activity against $2 \%$ trypsinized rabbit RBC's. The crude latex sample S2 (Musa acuminata) exhibits high lectin activity of 4096HU/mg, sample $S 4$ (Euphorbia geniculate) exhibit moderate lectin activity of $128 \mathrm{HU} / \mathrm{mg}$ and sample S5 (Abelmoschus esculentus) exhibits low lectin activity of $16 \mathrm{HU} / \mathrm{mg}$ titter value (Figures $1 \mathrm{~A}$ and $1 \mathrm{~B}$ and Table 1). Further, the stability of crude phloem exudate/ sap samples was evaluated by different kinetic parameters such as temperature and $\mathrm{pH}$. The results were found to be sample $S 2$, were extremely thermostable even at the temperature of $70^{\circ} \mathrm{C}$, whereas at $80{ }^{\circ} \mathrm{C}$, it lost $20 \%$ activity and it lost $40 \%$ activity at $100{ }^{\circ} \mathrm{C}$, sample $S 4$ thermostable even at the temperature $50{ }^{\circ} \mathrm{C}$, whereas at $80^{\circ} \mathrm{C}$, it lost $60 \%$ activity and it lost $70 \%$ activity at $100^{\circ} \mathrm{C}$ and sample $\mathrm{S} 5$ thermostable at $20{ }^{\circ} \mathrm{C}$, whereas at $80{ }^{\circ} \mathrm{C}$, it lost $80 \%$ activity and the activity of agglutinating was completely (95\%) inactivated at $100{ }^{\circ} \mathrm{C}$ (Figure 2A). Since the $\mathrm{pH}$ parameter of crude phloem exudate/sap sample $S 2$, retained its visible agglutinating activity, even at a high $\mathrm{pH}$ of 9-10 and it was more stable at $\mathrm{pH} 4-8$, But in the sample $S 4$ retained their agglutinating activity, even at the $\mathrm{pH}$ 6-8 and sample $S 5$ retained their agglutinating activity at $\mathrm{pH} 7$ (Figure 2B). It is evident that sample $S 2$ are stable even at a high temperature and the $\mathrm{pH}$ variations. It is clearly evident from this observation that the lectin, responsible for the cell agglutinating activity is exerting the anti-tumour and antiangiogenic potential.

Table 1: Screening of edible/dietary lectins for heamagglutination activity $(n=3)$.

\begin{tabular}{cccc}
\hline SI.No. & Plant Name & Family & Titre Value (HU/mg) \\
\hline 01 & Citrullus lanatus & Cucurbitaceae & 0 \\
02 & Musa acuminata & Musaceae & 4096 \\
03 & Manilkara zapota & Sapotaceae & 0 \\
04 & Euphorbia geniculate & Euphorbiaceae & 128 \\
05 & $\begin{array}{c}\text { Abelmoschus } \\
\text { esculentus }\end{array}$ & Malvaceae & 16 \\
\hline
\end{tabular}




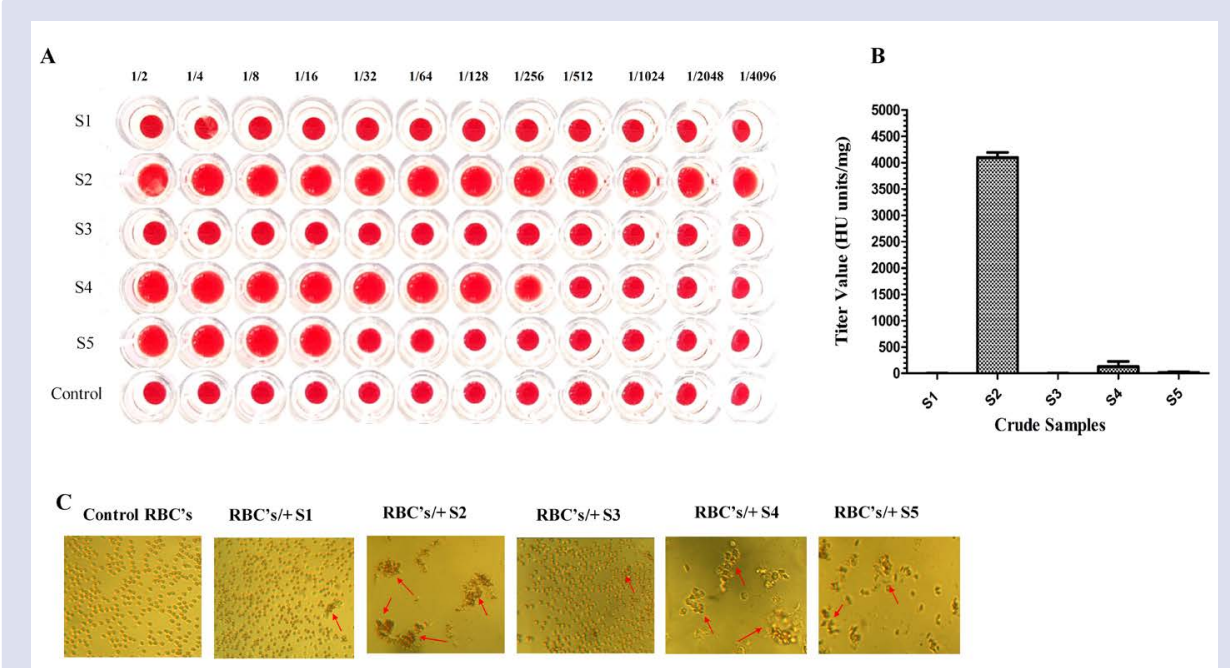

Figure 1: Cell agglutinating activity of crude phloem exudate/sap samples on trypsinized erythrocytes. The lectin activity in crude samples was assessed by haemagglutination assay. (A) Haemagglutination assay involves the serially diluted crude samples starting with $\mathrm{HU}$ units/mg concentration. The titter value of Sample $\mathrm{S} 1$ is $4096 \mathrm{HU}, \mathrm{S} 4$ is $128 \mathrm{HU}$ and $S 5$ is $16 \mathrm{HU}$ which shows the minimal concentration of the protein extracts, essential to display visible agglutination, (B) Titter value of the crude samples, (C) Morphological changes of RBCs cell after treating with the crude samples. The results were representative of three independent experiments $(n=3)$.

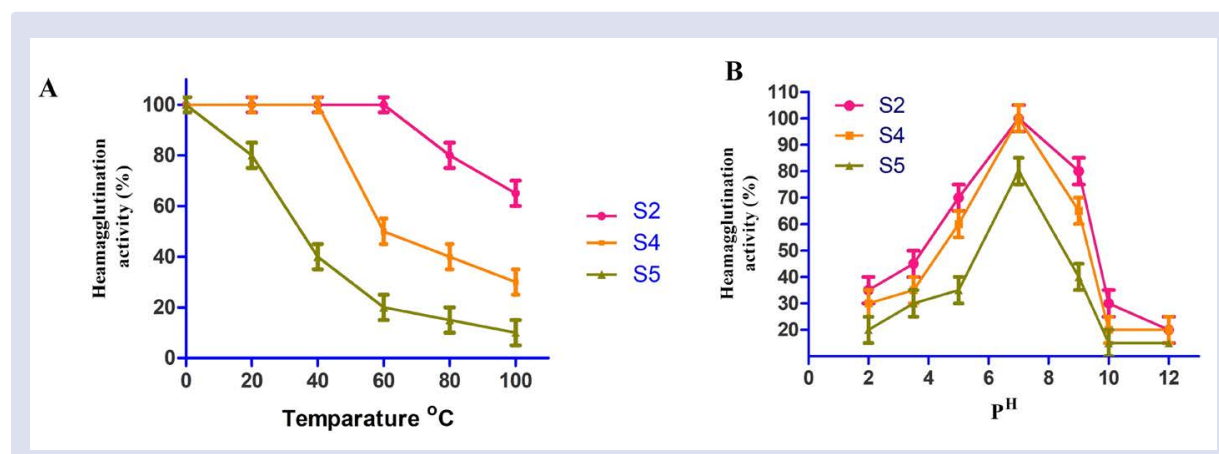

Figure 2: Evaluation of thermal and $\mathrm{pH}$ stability of crude phloem exudate/sap samples. (A) Thermal stability of crude samples agglutinating activity $\left(0^{\circ} \mathrm{C}-100{ }^{\circ} \mathrm{C}\right)$, (B) $\mathrm{pH}$ stability of crude samples agglutinating activity $(0-12 \mathrm{pH})$. The results were representative of three independent experiments $(n=3)$.

\section{Crude phloem exudate/sap samples decrease EAC cell viability in-vitro}

To determine cell viability of crude phloem exudate/sap samples in EAC cells and cells were incubated with different concentration of crude phloem exudate/sap samples $(200 \mu \mathrm{g}, 100 \mu \mathrm{g}, 50 \mu \mathrm{g}, 25 \mu \mathrm{g}$, $12.5 \mu \mathrm{g}, 6.25 \mu \mathrm{g}$ and $3.125 \mu \mathrm{g}$ ) for $4 \mathrm{hrs}$, stained With $0.25 \%$ trypan blue dye and counted under a microscope using a haemocytometer. Significant $100 \%$ of viability in control cells, $95 \%$ viability was observed in Sample $S 1,15 \%$ of viability in Sample $S 2,90 \%$ of viability in sample $S 3,35 \%$ of viability in sample $S 4$ and $75 \%$ of viability in sample $S 5$ at the concentration of $200 \mu \mathrm{g}$ after $4 \mathrm{hrs}$ of incubation (Figure 3).

Crude phloem exudate/sap samples inhibit cancer cell proliferation

Cytotoxicity activity of crude phloem exudate/sap samples was evaluated on the various human cancer cell lines of various origins and EAC of the mouse origin, human colon cancer (HT-29), breast cancer (MCF-7), cervical cancer (HeLa) and leukaemia (K562) cells. The obtained $\mathrm{IC}_{50}$ value against each of the cell lines is assessed by MTT assay (Table 2). It is apparent from the results that all the six cancer cell lines are sensitive to the sample $S 2$ and sample $S 4$ and sample $S 2$ which have inhibited the proliferative effectiveness in EAC, HeLa and MCF-7 cell lines when compared to the other cell lines and sample $S 4$ which have inhibited the proliferative effectiveness in EAC, HeLa and HT-29 cell lines when compared to the other cell lines. In contrast, sample $S 2$ and $S 4$ did not exhibit any changes in the viability of the normal Chang liver cell line (CCL-13), at a higher concentration of $1000 \mu \mathrm{g} / \mathrm{ml}$ and $\mathrm{IC}_{50}$ were found to be $835.75 \mu \mathrm{g}$ in sample $S 2$ and $840.5 \mu \mathrm{g}$ in sample S4 (Data not have shown). The graph indicates the prominent antiproliferative activity of crude phloem exudate/sap samples (Figures 4A-4C).

\section{Crude phloem exudate/sap samples inhibits in-ovo CAM angiogenesis}

The efficacy of the crude phloem exudate/sap of all the plant samples in inhibiting angiogenesis was studied in $\mathrm{rVEGF}_{165}$ induced CAM in-ovo angiogenesis model. The results of the in-ovo CAM assay revealed that none of the crude phloem exudate/sap samples was able to inhibit the blood vessel formation in the growing CAM of the chick embryo except sample S2, S4 and S5. A clear avascular zone around the implanted sample S2, S4 and S5 containing rVEGF165 were evident. There was a decrease of $\sim 80 \%$ of the growing blood vessel in the sample $S 2,65 \%$ 


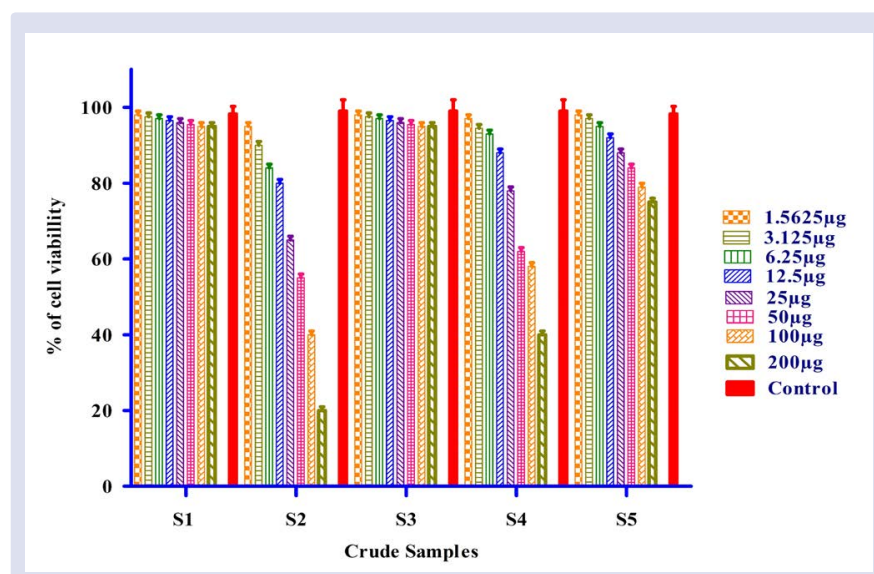

Figure 3: To evaluate in-vitro effect of crude phloem exudate/sap samples on EAC cell viability: (A) EAC cells were incubated with different crude phloem exudate/ sap extract of the plants such as Citrullus lanatus (S1), Musa acuminata (S2), Manilkara zapota (S3) Euphorbia geniculate (S4) and Abelmoschus esculentus (S5) and at different concentration i.e. $200 \mu \mathrm{g}$, $100 \mu \mathrm{g}, 50 \mu \mathrm{g}, 25 \mu \mathrm{g}, 12.5 \mu \mathrm{g} 6.25 \mu \mathrm{g}, 3.125 \mu \mathrm{g}$ and $1.5625 \mu \mathrm{g}$ for $4 \mathrm{hrs}$ at $37^{\circ} \mathrm{C}$. Percentage of viable cells were determined by tryphan blue dye exclusion method.

Table 2: $I C_{50}$ value of the sample $S 2$ and $S 4$ against the various human cancer cell lines.

\begin{tabular}{ccc}
\hline Cell Line Name & IC $_{50}$ Value Sample S2 & IC $_{50}$ Value Sample S4 \\
\hline HeLa & $40.25 \mu \mathrm{g} \pm 1.0$ & $46.75 \mu \mathrm{g} \pm 1.2$ \\
HT-29 & $62.40 \mu \mathrm{g} \pm 1.5$ & $48.25 \mu \mathrm{g} \pm 1.5$ \\
K562 & $73.75 \mu \mathrm{g} \pm 1.5$ & $76.75 \mu \mathrm{g} \pm 1.3$ \\
MCF-7 & $42.50 \mu \mathrm{g} \pm 1.2$ & $63.50 \mu \mathrm{g} \pm 1.0$ \\
\hline
\end{tabular}

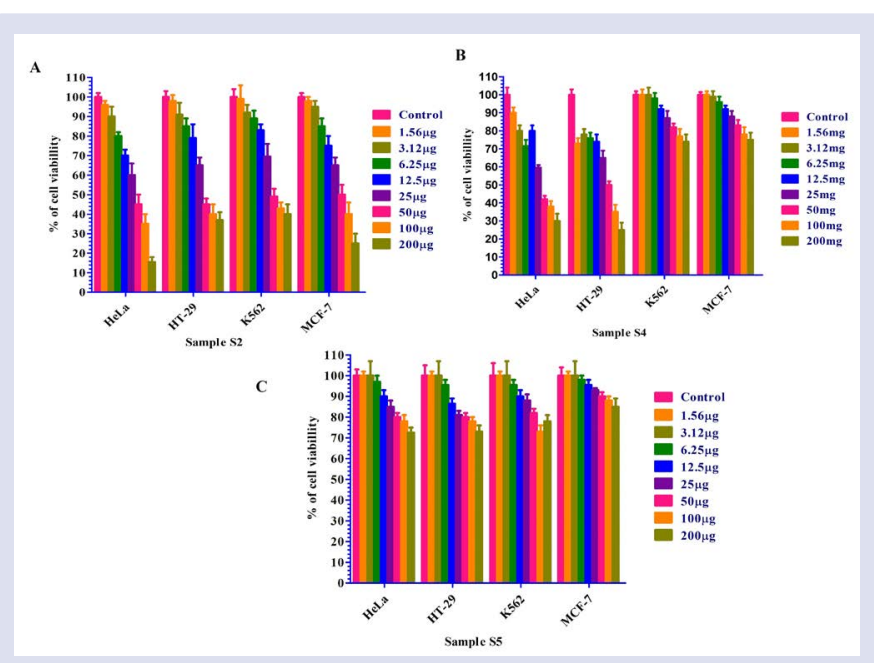

Figure 4: To evaluate the in-vitro cytotoxic effect of crude phloem exudate/sap samples on different human cancer cell line with different concentration $(200 \mu \mathrm{g}$ to $1.562 \mu \mathrm{g})$. (A-C) In-vitro cytotoxic potential of crude samples on cancer cells.

inhibition in the sample $S 4$ and 35\% inhibition in the sample $S 5$ treated CAM (Figures 5A-5F).

\section{Crude phloem exudate/sap samples induces apoptosis of EAC cells in-vitro}

To evaluate the isolated crude phloem exudate/sap samples induced cell death of EAC cells in-vitro. EAC cells were treated with crude phloem exudate/sap samples were subjected to apoptosis analysis through Giemsa staining and the result shows the apoptotic morphological characteristics such as apoptotic body's cells, plasma membrane rupture, chromatin condensation, membrane blebbing and the irregular shape of cells in the treated cells but not in the control cells (Figure 6A). Further, fluorescent apoptotic morphology was assessed by $\mathrm{Ao} / \mathrm{EtBr}$ dual staining method. Acridine orange is a vibrant dye and will stain both live and dead cells. Ethidium bromide will stain only the cells that have lost their membrane integrity. Live cells will look uniformly green. Early apoptotic cells will stain green and contain bright green dots in the nuclei as a consequence of chromatin condensation and nuclear fragmentation. Late apoptotic cells will also incorporate ethidium bromide and therefore stain orange, but, in contrast to necrotic cells, the late apoptotic cells will show condensed and often fragmented nuclei. Necrotic cells stain orange but have a nuclear morphology resembling that of viable cells, with no condensed chromatin observed in treated EAC cells but not in control EAC cells (Figure 6B). Sample (S2) and sample (S4) exhibits potent apoptotic activity in EAC cells.

\section{Crude phloem exudate/sap samples treatment induces caspase-3 mediated apoptosis}

The evaluation of apoptotic pathway was further carried out by determining the DNA fragmentation assay. EAC cells treated with crude phloem exudate /sap sample $S 2$ and $S 4$ showed distinctive DNA fragmentation which then leads to the formation of DNA laddering that had higher apoptotic cells while the DNA of S1, S3 and S5 sample cells did not show any fragmentation (Figure 7A). Caspases have been shown to play a vital role in apoptosis induced by several deleterious and physiologic provocations. Inhibition of caspases can delay apoptosis, associating a potential role in drug screening efforts. Further investigation on the molecular insights, underlying apoptotic downstream signalling pathway revealed that the activation of caspase-3 protease in crude phloem exudate/sap samples treatment induced EAC cell death. In order to check the involvement of caspase- 3 upstream activator of endonuclease, the cells were treated with or without caspase-3- inhibitor (Ac-DEVD-CHO), prior to the treatment with crude samples. The results clearly suggest that the DNA fragmentation is due to increased endonuclease activity but the Ac-DEVD-CHO, a specific inhibitor of caspase-3 enzyme inhibited the DNA fragmentation (Figure 7B). DNA Degradation and caspase-3 inhibitor assays showed that the sample $S 2$ and $S 4$ induce Caspase- 3 mediated apoptosis in EAC cells. The above data is clear the confirmation of the induction of proapoptotic activity of crude phloem exudate/sap samples.

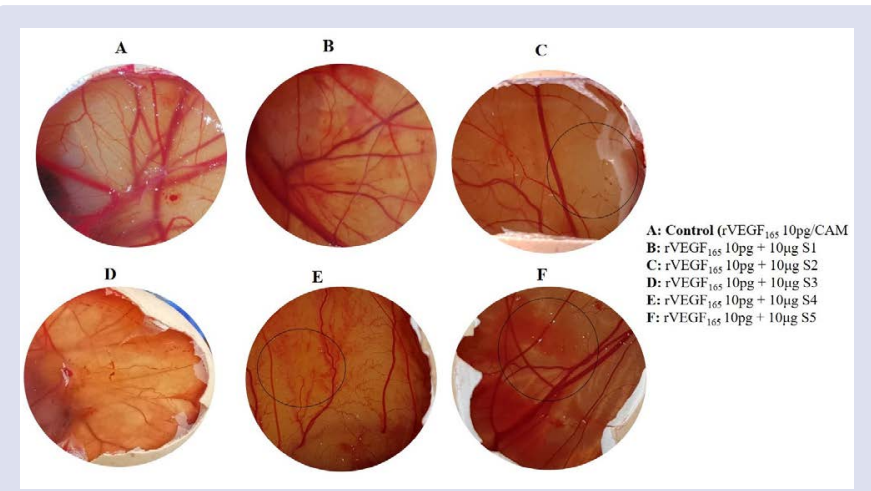

Figure 5: The anti-angiogenic activity of isolated crude phloem exudate/sap samples in in-ovo angiogenic CAM model. (A) In-ovo CAM photographs showing the crude phloem exudate/sap samples inhibit the blood vessel formation in the growing CAM of the chick embryo except for sample S1 and S3. A clear avascular zone around the implanted samples containing rVEGF165 was evident. 


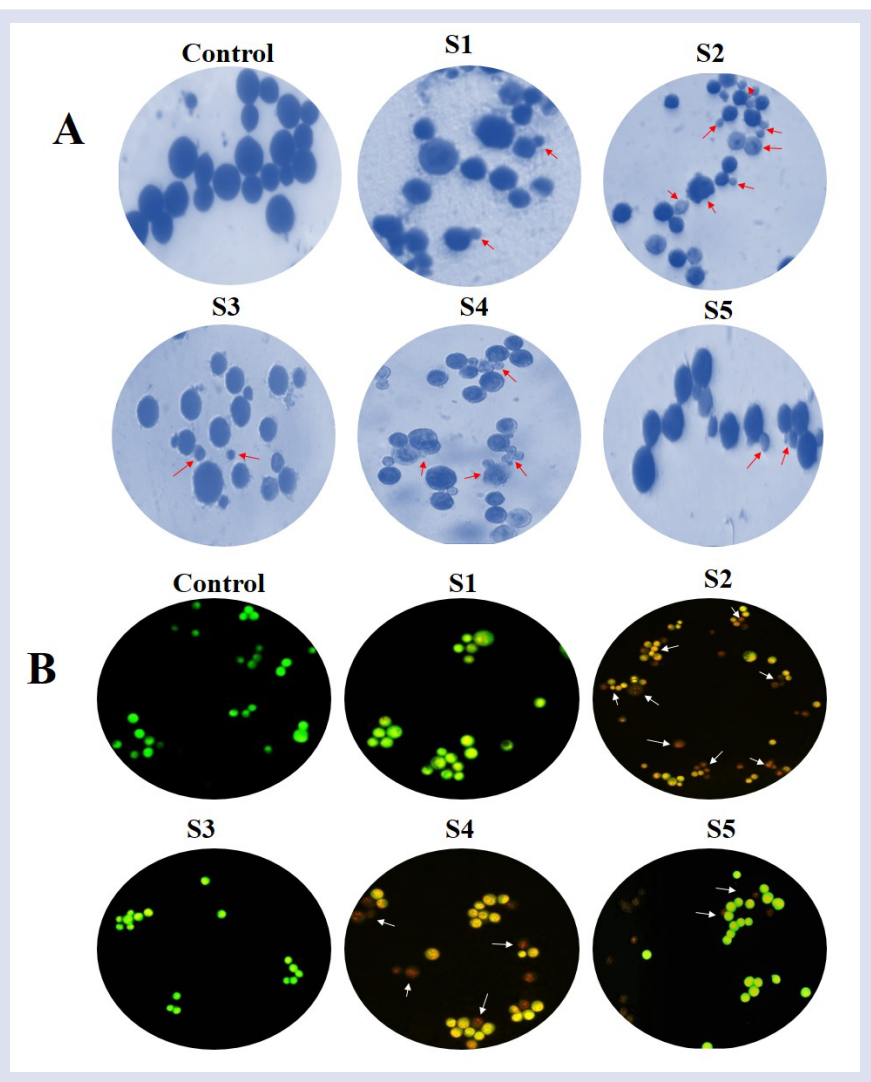

Figure 6: In-vitro effect of crude phloem exudate/sap samples on induction of EAC cell apoptosis. Pro-apoptotic effect of crude samples were analysed by nuclear staining technique after treatment, (A-B) Treated and untreated EAC cells were fixed in methanol/acetic acid solution (3:1) and stained with Giemsa and $\mathrm{AO} / \mathrm{Et} \mathrm{Br}$ to visualize apoptotic features such as plasma membrane degradation, membrane blebbing or apoptotic bodies upon treatment when compared to control cell morphology and the results were documented. Arrow marks in the image indicate the apoptotic morphological changes of cells (Early, late apoptotic and Necrotic cells). Sample (S2) and Sample (S4) exhibits potent pro-apoptotic activity when compared to other samples.

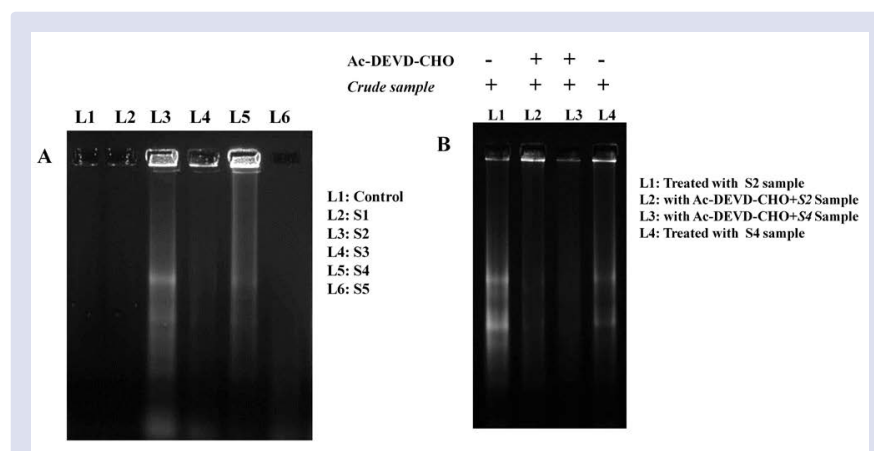

Figure 7: In-vitro pro-apoptotic effect of crude phloem exudate/sap samples of EAC cells were analysed by Caspase-3 inhibitor and DNA fragmentation Assay. DNA was isolated from cells treated with and without crude phloem exudate/sap samples and resolved on 1.5\% agarose gel for DNA degradation. (A): Crude samples induces genomic DNA fragmentation. Lane 1: Control DNA, Lane 2:S1, Lane 3:S2, Lane 4:S3, Lane 5: S4, Lane 6:S5 (B) Effect of caspase-3 inhibitor on crude samples induced DNA fragmentation. Lane 1: $S 2$ treated sample, Lane 2: with AcDEVD-CHO+S2 Sample, Lane 3: with Ac-DEVD-CHO+S4 Sample and Lane 4: $S 4$ treated sample.

\section{DISCUSSION}

Medicinal herbs and plants continue to play a significant role in drug discovery and development, predominantly in cancer research. The overwhelming contribution of natural products to the increase of the chemotherapeutic arsenal is evidenced by the fact that $50 \%$ of all the anticancer drugs approved worldwide between 1940 and 2006 were either natural products or natural products derived many of these novel anticancer agents have a history of using. In early 1991, Liener reported that lectin from soybean exhibited an effective anti-tumour activity which inhibited the growth of a transplanted tumour in rats. ${ }^{30,31}$ Since then consequent years witnessed an explosive growth in the use of lectins in biomedical and cancer research. Apart from the potent cytotoxicity towards cancer cells, plant lectins are also indicated for the reduction of treatment associated side-effects as adjuvant agents during chemotherapy and radiotherapy in Europe for several years. ${ }^{32}$ The presence of lectin has been detected in a large number of plant species seen worldwide, but very few lectins have been separated in pure form and these attempts were mainly done in global flora. So, the present investigation demonstrates the wide occurrence of lectins in locally available plants. For many years, it was alleged that lectins are a toxic substance which may harmful to the physiological system. According to Dr. Peter J. D’Adamo "eat right for your blood type", which explains the significant effect of lectin in the diet. Lectins present in the sap/phloem exudates which plays an important role in the plant defence system as well. ${ }^{33}$ The plants that showed haemagglutination come under different families. There are many reports about the presence of lectins in the medicinal plant. This suggests that the lectins were not confined to a particular family. Some of the plants included in this study are used as food material while others are utilized in the indigenous system of medicine. Based on the early reports, in this present illumination, we screened the 05 edible/dietary plant phloem exudates/sap for lectin activity by using rabbit RBCs. Out of the 05 plants screened, 3 plants showed the presence of haemagglutinating activity against the rabbit RBCs tested, which are Musa acuminata, Euphorbia geniculate and Abelmoschus esculentus. The remaining 2 plants don't show the haemagglutinating activity against the rabbit RBCs tested, which are citrus lanatus and Manilkara zapota. Phloem exudate/sap from the Musa acuminata exhibit high lectin activity against all the kind of RBCs tested and it belongs to Musaceae family, Moderate lectin activity in Euphorbia geniculate, it belongs to Euphorbiaceae family and low lectin activity in Abelmoschus esculentus, it belongs to Malvaceae family (Figures $1 \mathrm{~A}-1 \mathrm{C}$ and Figures $2 \mathrm{~A}-2 \mathrm{~B}$ ). The majority of the lectins from Musaceae family were mannose-specific lectin which is reported previously. ${ }^{34}$ Edible/Dietary lectins from the plant origin spread an overhaul due to its promising anti-cancer tools in the field of cancer biology. Lectins were used as diagnosing marker and massacre agents in cancer treatment. ${ }^{35}$

Here, we report the anti-cancer activity for the first time of the crude phloem exudates/ sap samples with a potent lectin activity, real as a striking approach for cancer treatment without damaging the host. As evident from our results, crude phloem exudate/sap sample $S 2$, $S 4$ and $S 5$ decrease cell viability in EAC cells in-vitro when compared to the other samples in tryphan blue assay (Figure 3). Further, we evaluate the cytotoxic effect of crude phloem exudates/sap sample from different plants was assessed by MTT assay by using different human cancer cell lines in-vitro. sample S2, S4 and sample S5 kills cancer cells at a lower concentration and exhibits the potent cytotoxic effect in EAC, HeLa, HT-29 and MCF-7 cell line when compared to the other cell lines (Figures 4A-C and Table 2). This may due to the presence of soluble bioactive peptide /protein molecules and other small molecules which may responsible for the cytotoxic potential of cancer cells. 
The growth of a tumour and metastasis are dependent on the formation of new blood vessels. Most elegant investigation of the correlation between the onset of angiogenesis and tumour growth was carried out by Folkman et al. ${ }^{36}$ The tumour growth and metastasis are wellconnected with several angiogenic growth factors, nutrients, oxygen supply etc. ${ }^{37,38}$ Normal angiogenesis heavily depends on the vascular endothelial growth factor (VEGF) and its isoforms. VEGF plays a major role in developing the microvessel density in the pre-existing blood vessel and contributes to the tumour development. This finding suggests that microvessel density is a valuable prognostic factor..$^{39}$ Our study reveals that the crude phloem exudate/sap samples from the $S 2$, $S 4$ and S5 plants have expressively reduced the blood vessels in nontumoral $\mathrm{rVEGF}_{165}$ induced CAM assay and it helps to prove the $S 2$, $S 4$ and $S 5$ samples are capable to bock the newly forming blood vessel and it's an anti-angiogenic activity. This clearly shows that angiogenesis is closely linked to the microvessel density of the tissue and clinical assertiveness of a tumour (Figures 5A-5F).

The literature has shown that edible/dietary plant lectins can act as an auspicious agent to induce polyclonal activation of lymphocytes ${ }^{40}$ and they kill cancer cells through apoptosis, in-vitro. ${ }^{41-45}$ Apoptosis is a significant way to maintain cellular homeostasis between cell division and cell death. The fragmentation of DNA/chromosomes as an important biochemical process occurs during apoptosis. One of the failures of tumour cells is to initiate apoptosis, following the DNA damage. The failure in the apoptosis leads to malignancy, an important hallmark of cancer. ${ }^{46}$ The primary approaches in the cancer treatment are reinstalling the apoptotic machinery within cancer cells or the induction of apoptosis in neoplastic cells which could be an effective measure in the controlling of cancer. So, the induction of apoptosis in cancer cells is one of the useful strategies for anticancer drug development with minimal or no side effects. In this admiration, many studies were performed for screening of apoptosis-inducing lectin compounds from phloem exudate/sap sample from the medicinal plants. In the present study, we found that $S 2, S 4$ and $S 5$ samples showed significant anti-proliferative and induction of apoptosis in EAC cells invitro. The S2, S4 and S5 sample treated cells exhibit the morphological and biochemical changes that characterize the apoptosis. Cells and nuclear shrinkage, chromatin condensation, the formation of apoptotic bodies and phagocytosis by neighbouring cells characterize the main morphological changes of the apoptosis process. ${ }^{47}$ Giemsa stain, AO/ $\mathrm{EtBr}$ staining study very clearly showed that cell and nuclear shrinkage, apoptotic body formation in the treated cell when compared to untreated cells (Figures 6A-6B). Cleavage of chromosomal DNA into oligonucleosomal size fragments is a biochemical hallmark of apoptosis. ${ }^{48}$ Caspases have been shown to play a vital role in apoptosis induced by several deleterious and physiologic provocations. Inhibition of caspases can delay apoptosis, associating a potential role in drug screening efforts. Caspase-3 inhibitor can be used to inhibit caspase-3 activity and to study events downstream of caspase-3 activation. Further Caspase-3 inhibitor assay and DNA fragmentation study reveal the apoptosis-inducing activity of crude exudate samples (Figures 7A7B). Similarly, a large number of natural foodstuffs have proven the anti-cancer property of inducing apoptosis pathways in transformed cells during carcinogenesis process. ${ }^{49}$ As it is non-toxic, it is possible to take up further studies. Hence, purification and characterisation of the lectin component(s) and investigation of the molecular mechanism associated with anti-angiogenic and apoptotic inducing pathways are in progress.

\section{CONCLUSION}

In conclusion, our study clearly demonstrates that the isolated crude phloem exudate/sap samples strongly inhibit agglutination in rabbit erythrocytes and is shows the potent cytotoxic effect in the different human cancer cell lines. Crude phloem exudate/sap samples induce cell viability and apoptosis in EAC cells in-vitro and the formation of new blood vessels in In-ovo CAM model. Induction of apoptosis and inhibition of anti-angiogenic properties of isolated crude phloem exudate/saps samples is surely given us a ray of positivity in the field if new anti-cancer drug discovery. However, we have to carry out a further additional experiment to purify and characterize the bioactive lectin components from the potent sample which is responsible for proapoptotic, anti-angiogenic activity and mechanism involved.

\section{FUNDING DETAILS}

This research work was not supported by any funding agencies.

\section{ACKNOWLEDGEMENT}

The authors acknowledge the Teresian Research Foundation and P.G. Department of Biotechnology, Teresian College (affiliated to the University of Mysore) for providing animal cell culture facility. The authors would like to thank the Department of Pharmacy, Bharathi College of Pharmacy, KM Doddi, Mandya and Karnataka for providing the animal house facility.

\section{CONFLICTS OF INTEREST}

The authors declare that there is no conflict of interest regarding the publication of this paper.

\section{ABBREVIATIONS}

EAC: Ehrlich Ascites Carcinoma; HeLa: Human Cervical Cancer Cell Line; MCF-7: Michigan Cancer Foundation-7 (Human Breast Cancer Cell line); HT-29: Human Colorectal Adenocarcinoma Cell Line; K-562: Leukaemia Cancer Cell Line; CCL-13: Chang Liver Cell Line (Normal); MTT: (3-(4,5-Dimethylthiazol-2-yl) -2,5-Diphenyltetrazolium Bromide); AO/Et Br: Acridine orange/Ethidium bromide; RBCs: Red Blood cells; PBS: Phosphate Buffer Saline;CAM: Chorio Allantoic Membrane; rVEGF165: Recombinant Vascular Endothelial Growth Factor 165; HA: Haemagglutination; S1: Citrullus lanatus; S2: Musa Acuminata; S3: Manilkara zapota; S4: Euphorbia geniculate; S5: Abelmoschus esculentus.

\section{REFERENCES}

1. Boyd WC, Shapleigh E. Antigenic relations of blood group antigens as suggested by tests with lectins. J Immunol. 1954;73(4):226-31.

2. Dias RD, Machado LD, Migliolo L, Franco OL. Insights into animal and plant lectins with antimicrobial activities. Molecules. 2015;20(1):519-41.

3. Henry NL, Hayes DF. Cancer biomarkers. Mol Oncol. 2012;6(2):140-6.

4. Pinho SS, Reis CA. Glycosylation in cancer: mechanisms and clinical implications. Nat Rev Cancer. 2015;15(9):540-55.

5. Preetha A, Ajaikumar BK, Chitra S, Kuzhuvelil BH, Sheeja TT, Oiki SL, et al. Cancer is a preventable disease that requires major lifestyle changes. Pharma Rese. 2008;25(9):2097-116

6. Duthie SJ, Jenkinson AM, Crozier A, Mullen W, Pirie L, Kyle J, et al. The effects of cranberry juice consumption on antioxidant status and biomarkers relating to heart disease and cancer in healthy human volunteers. Eur J Nutr. 2006;45(2):113-22.

7. Manen JF, Pusztai A. Immunohistochemical localization of lectin in cells of Phaseolus vulgaris L. seeds. Planta. 1982;155(4);328-34.

8. Singh G, Kumar P. Phytochemical study and screening for antimicrobial activity of flavonoids of Euphorbia hirta. Int J Appl Basic Med Res. 2013;3(2):111-6.

9. Iswariya S, Uma TS. Evaluation of in vitro anti-inflammatory and antimicrobial activity of aqueous and methanolic seed extracts of citrullus lanatus. Int J Pharm Pharma Sci. 2017;9(5):29-33.

10. Gupta A, Singh A, Prasad R. A review on watermelon (Citrullus lanatus) medicinal seeds. Journal of Pharmacognosy and Phytochemistry. 2018;7(3):2222-5.

11. Mital K, Sumitra C. Evaluation of antioxidant and antimicrobial properties of Manilkara zapota L. (chiku) leaves by sequential soxhlet extraction method Asian Pac J Trop Biomed. 2012;2(3):S1526-33.

12. Ortaç D, Cemek M, Karaca T, Buyukokuroglu ME, Ozdemir ZO, Kocaman AT, et al. In vivo antiulcerogenic effect of okra (Abelmoschus esculentus) on ethanol induced acutegastric mucosal lesions. Pharm Biol. 2018;56(1):165-75.

13. Mohammad Z, Saleha A. Musa paradisiacal L. and Musa sapientum L.: A Phytochemical and Pharmacological Review. Journal of Applied Pharmaceutical Science. 2011;1(5):14-20 
14. Ramu R, Shirahatti PS, Nanjunda SS, Zameer F, Dhananjaya BL, Nagendra $\mathrm{PMN}$. Assessment of in vivo antidiabetic properties of umbelliferon and lupeol constituents of banana (Musa sp. var. nanjangud rasa bale) flower in Hyperglycaemic rodent model. Plosone. 2016;11(3):e0151135.

15. Ramu R, Shirahatti PS, Dhanabal SP, Zameer F, Dhananjaya BL, Nagendra PMN. Investigation of Antihyperglycaemic Activity of Banana (Musa sp. Var. Nanjangud rasa bale) Flower in Normal and Diabetic Rats. Phcog Mag. 2017;13(51):417-23.

16. Read SM, Northcote DH. Subunit structure and interactions of the phloem proteins of Cucurbita maxima (pumpkin). Eur J Biochem. 1983;134(3):561-9.

17. Lowry OH, Rosebrough NJ, Farr AL, Randall RJ. Protein measurement with the Folin phenol reagent. J Biol Chem. 1951;193(1):265-75.

18. Pramod SN, Venkatesh YP. Utility of pentose colorimetric assay for the purification of potato lectin, an arabinose-rich glycoprotein. Glycoconj J. 2006;23(7):481-8.

19. Chan YS, Ng TB. A lectin with highly potent inhibitory activity toward breast cancer cells from edible tubers of Dioscorea opposite cv. Nagaimo. Ploseone. 2013;8(1):e54212.

20. Jyoti BC, Balaji KS, Jayarama S, Wethroe K. Evaluation of apoptogenic effects of Averrhoa bilambi extract on enrlich ascites carcinoma bearing mice. Asian $J$ Pharm Clin Res. 2016;9:348-52.

21. Johnson $S$, Nguye V, Coder D. Assessment of cell viability. Curr Protoc Cytom. 2013;65(1):921-6

22. Preethi SD, Srinivas BK, Shivaramu PD, Ramesh ST, Jayarama S, et al. Synthesis, characterization of 4-Anilino-6, 7-Dimethoxy Quinazoline Derivatives as potential anti-angiogenic agents. Anticancer Agents Med Chem. 2017;17:1931-41.

23. Balaji KS, Priyanka S, Preethi SD, Chandrashekara KT, Lokesh S, Rangappa KS et al. Angio-suppressive effect of Clitoria Ternatea flower extracts is mediated by HIF- $1 \alpha$ and down-regulation of VEGF in Murine carcinoma model. Med Chem. 2016;6(7):515-20.

24. Lingaraju GS, Balaji KS, Jayarama S, Anil SM, Kiran KR, Sadashiva MP. Synthesis of new coumarin tethered isoxazolines as potential anticancer agents. Bioorg Med Chem Lett. 2018;28(23-24):3606-12.

25. Shivaprakash P, Balaji KS, Lakshmi GM, Chandrashekara KT, Jayarama S. Methanol extract of Caesalpinia bonducella induces apoptosis via up-regulation of Bax and activation of PARP in Ehrlich Ascites tumor cells. Med Aromat Plants. 2016;5(273).

26. Roopashree R, Mohan CD, SwaroopTR, Jagadish S, Raghava B, Balaji KS, et al. Novel synthetic bisbenzimidazole that targets angiogenesis in Ehrlich ascites carcinoma bearing mice. Bioorg Med Chem Lett. 2015;25(12):2589-93.

27. Madhu CS, Srinivas BK, Shankar J, Sharadha AC. Anti-cancer and antiangiogenic effects of partially purified lectin from Praecitrullus fistulosus fruit on in vitro and in vivo model. Biomed and Pharmacother. 2017:96:1299-309.

28. Preethi SD, Balaji KS, Prasanna DS, Swaroop TR, Shankar J, et al. Pro-apoptotic activity of novel 4-anilinoquinazoline derivatives mediated by up-regulation of bax and activation of poly (ADP-ribose) phosphatase in ehrlich ascites carcinoma cells. Asian J Chem. 2017;29(4):896-904.

29. Srinivas BK, Shivamadhu MC, Jayarama S. Angio-suppressive effect of partially purified lectin-like protein from musa acuminata pseudostem by inhibition of VEGF-mediated neovascularization and induces apoptosis both in vitro and in vivo. Nutrition and Cancer. 2018.

\section{GRAPHICAL ABSTRACT}

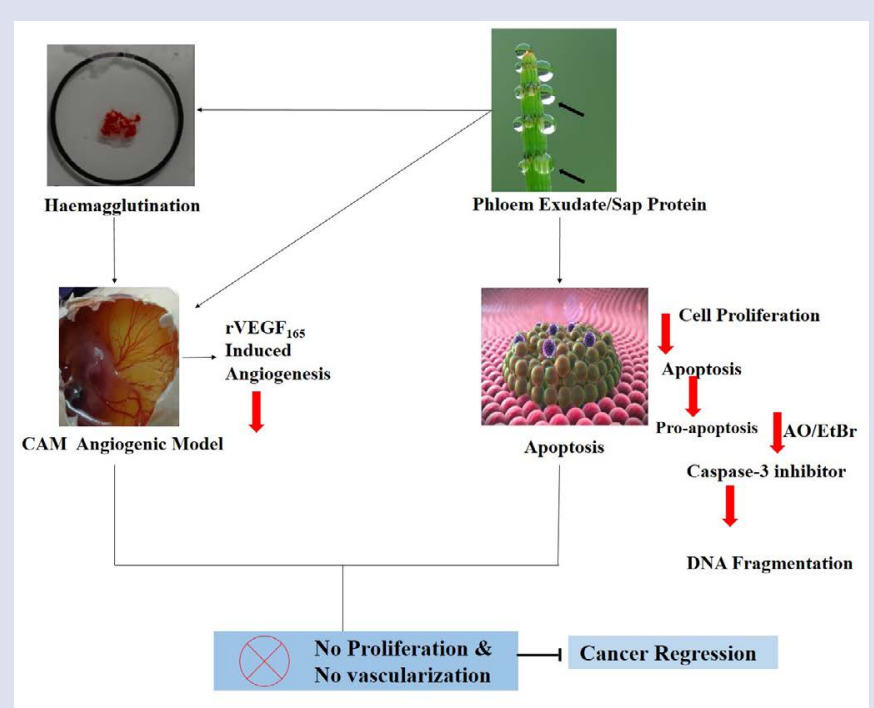

30. Hivrale A, Ingale A. Plant as a plenteous reserve of lectin. Plant Signal Behav. 2013;8(12):e26595

31. Liener IE. From soybeans to lectins: a trail of research revisited. Carbohydr Res.1991;213:1-5.

32. Liu B, Bian $H$, Bao J. Plant lectins: Potential antineoplastic drugs from bench to clinic. Cancer Lett. 2010;287(1):1-12

33. Peumans WJ, Van Damme EJ. The role of lectins in plant defence. Histochem J. 1995;27(4):253-71.

34. Singh SS, Devi SK. Ng TB. Banana lectin: a brief review. Molecules. 2014;19(11):18817-27.

35. Mody R, Anataram J, Chaney W. Use of lectins as diagnostic and therapeutic tools for cancer. J Pharmacol Toxicol Methods. 1995;33(1):1-10.

36. Folkman J, Shing Y. Angiogenesis. J Biol Chem. 1992;267(16):10931-4.

37. Folkman J. Tumor angiogenesis therapeutic implications. N Engl J Med 1971;285(21):1182-6.

38. Folkman J. Fundamental concepts of angiogenic process. Curr Mol Med. 2003;3(7):643-51.

39. Janice AN, Elizabeth MM, Kemp TH, Michelle SM, Yeo KT, Yeo TK, et al. Pathogenesis of ascites tumor growth: vascular permeability factor, vascular hyper permeability and ascites fluid accumulation. Cancer Res. 1995;55(2):3608.

40. Qing D, Tsutomu S, Yumiko T, Yasuhiro Y, Nobuyuki Y, Yuji K. Stimulation of IFN-production by garlic lectin in mouse spleen cells: Involvement of IL12 via activation of P38 MAPK and ERK in macrophages. Phytomedicine. 2011;18(4):309-16.

41. Kim M, Rao MV, Tweardy DJ, Prakash M, Galili U, Gorelik E. Lectin-induced apoptosis of tumor cells. Glycobiology. 1993;3(5):447-53.

42. Kim MS, So HS, Lee KM, Park JS, Lee JH, Moon SK, et al. Activation of caspases cascades in Korean mistletoe (Viscum album varcoloratum) lectinIl-induced apoptosis of human myeoleukemic U937 cells. Gen Pharmacol. 2000;34(5):349-55

43. Seifert G, Jesses $P$, Laengler A, Reindi T, Luth M, Lobitz S, et al. Molecular mechanism of mistletoe plant extract-induced apoptosis in acute leukaemia in vivo and in vitro. Cancer Lett. 2008:264(2):218-28.

44. Suen YK, Fung KP, Choy YM, Lee CY, Chan CW, Kong SK. Concanavalin A induced apoptosis in murine macrophage PU5-1.8 cells through clustering of mitochondria and release of Cytochrome C. Apoptosis. 2000;5(4):369-77.

45. Fernandez T, Cerda ZP, Aulicino P, Caldas LE, Wagner M, Ricco R, et al. Immunobiological features of the galactoside lectin L-LC isolated from the Argentine mistletoe Ligaria cuneifolia. J Ethnopharmacol. 2003;85(1):81-92.

46. Hanahan D, Weinberg RA. The hallmarks of cancer. Cell. 2000;100(1):57-70.

47. Lockshin RA, Williams CM. Programed cell death-II. Endocrine potentiation of the breakdown of the intersegmental muscles of silkmoths. J Ins Physiol. 1964;10(4):643-9.

48. Jin S, Dipapola RS, Mathew R, White E. Metabolic catastrophe as a means to cancer cell death. J Cell Sci. 2007;120(3):379-83.

49. Mukhtar E, Adham VM, Khan N, Mukhta H. Apoptosis and autophagy induction as a mechanism of cancer prevention by naturally occurring dietary agents. Curr Drug Targets. 2012;13(14):1831-41.

\section{SUMMARY}

- Crude phloem exudate/sap samples show strong haemagglutination activity.

- Crude phloem exudate/sap samples exhibit potent anticancer activity against the various human cancer cell lines in in-vitro.

- Crude phloem exudate/sap samples significantly decrease the cell viability and apoptosis in EAC cells in-vitro.

- Crude phloem exudate/sap samples reduce the newly formed microvessel (blood vessels) in VEGF $_{165}$ induced in-ovo CAM angiogenic model.

- Interestingly Crude phloem exudate/sap samples did not show any toxicity in normal Chang liver cell line. 


\section{ABOUT AUTHORS}

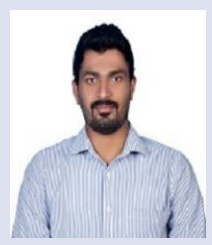

Balaji Kyathegowdanadoddi Srinivas: is a Ph.D. scholar at PG Department of Biotechnology (Affiliated to University of Mysore), Teresian Research Centre, Teresian College, Mysore. Specialization in Lectin and Tumor biology.

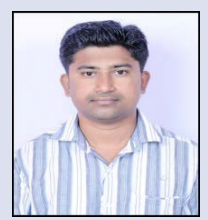

Madhu Chakkere Shivamadhu: is an Assistant professor at PG Department of Biotechnology (Affiliated to University of Mysore), Teresian Research Centre, Teresian College, Mysore. His research focused on Lectin Biology.

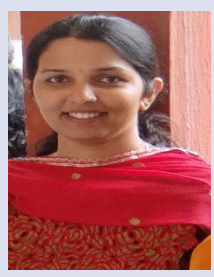

Preethi Saligrama Devegowda: is a Research Associate at Institution of Excellence, Vijnana Bhavan, Manasagangotri, University of Mysore, Mysuru. Her research focused on drugs discovery of herbal plants, Synthesis of novel small molecules and its anticancer activity.

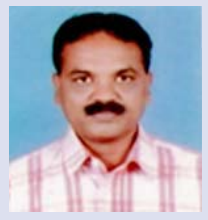

Gurukar Mathew: is a Professor at Department of Botany, Bharthi college (Affiliated to University of Mysore), KM Doddi, Mandya. Specialized in Identification of rare Plant species (Ethnomedicinal and Endangered plants) and it's biological activity.

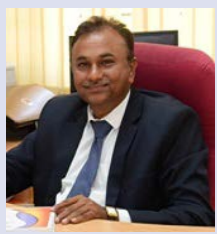

Theethagounder Tamizhmani: is a Director and Professor at Department of Pharmacy, Bharathi College of Pharmacy, Bharathi Nagara, KM Doddi, Mandya, Working on drug discovery and Pharmacology.

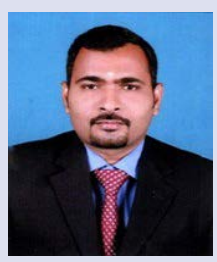

Senthilkumar Gnanavadevel Prabhakaran: is a Principal and Assistant Professor at Department of Pharmacy, Bharathi College of Pharmacy, Bharathi Nagara, KM Doddi, Mandya, Working on herbal plants drug discovery and Pharmacology.

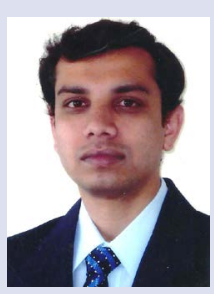

Shankar Jayarama: is an Assistant Professor at PG Department of Biotechnology (Affiliated to University of Mysore), Teresian Research Centre, Teresian College, Mysore. Specialization in Apoptosis, Angiogenesis, Inflammation and Signal Transduction.

Cite this article: Srinivas BK, Shivamadhu MC, Devegowda PS, Mathew G, Tamizhmani T, Gnanavadevel Prabhakaran S, et al. Screening and Evaluation of Lectin and Anti-Cancer Activity from the Phloem Exudate/Sap of the Indian Dietary Ethnomedicinal Plants. Pharmacog J. 2019;11(3):570-8. 